ISSN 1392-3196 / e-ISSN 2335-8947

Zemdirbyste-Agriculture, vol. 100, No. 2 (2013), p. 199-204

DOI $10.13080 / \mathrm{z}-\mathrm{a} .2013 .100 .026$

\title{
Glucosinolates as arsenal for defending Brassicas against cabbage flea beetle (Phyllotreta spp.) attack
}

\author{
Tanja BOHINC ${ }^{1}$, Iztok Jože KOŠIR ${ }^{2}$, Stanislav TRDAN ${ }^{1}$ \\ ${ }^{1}$ University of Ljubljana \\ Jamnikarjeva 101, SI-1111 Ljubljana, Slovenia \\ E-mail: tanja.bohinc@bf.uni-lj.si \\ ${ }^{2}$ Slovenian Institute of Hop Research and Brewing \\ SI-3310 Žalec, Slovenia
}

\begin{abstract}
Feeding of cabbage flea beetles on various Brassica species can reduce crop productivity. While progressing towards the goal of reducing the use of synthetic pesticides and promotion of environmental protection, we wish to exploit plants' natural resilience. The results of our study carried out in 2009-2010 show that glucosinolate contents vary with plant species and plant organs. Among the indole glucosinolates, all Brassica species (cabbage, oil radish, oil seed rape and white mustard) displayed the presence of glucobrassicin, whose influence on cabbage flea beetles varied according to the plant species. We established that gluconasturtiin content in oil seed rape negatively $(r=-0.99)$ influenced the feeding of flea beetles, while the progoitrin $(r=0.51)$, sinalbin $(r=0.61)$ and gluconapin $(r=0.67)$ stimulated the feeding of flea beetles in this crop. No significant influence of glucobrassicin on flea beetles was detected in oilseed rape, while this glucosinolate negatively influenced the intensity of flea beetles feeding in oil radish and white mustard $(r=-0.32, r=-0.64)$. Oil radish thus proved to be the most suitable species as a trap crop for flea beetles. We conclude that protection of the Brassicas against flea beetles can depend on glucosinolate content, but additional tests to confirm practical meaning of this study in environmentally acceptable cabbage production are required.
\end{abstract}

Key words: cabbage, glucosinolates, oil radish, oil seed rape, Phyllotreta spp., white mustard.

\section{Introduction}

Plants can react to herbivores in two ways - by defending and by developing tolerance (Breuker et al., 2007). Besides morphological defensive factors, e.g., waxy epidermis (Trdan et al., 2009), trichomes (Carmona et al., 2011) etc., plants can defend against harmful pests also with secondary metabolites (Breuker et al., 2007; Jõgar et al., 2008).

The typical secondary metabolites, characteristic of the Brassicaceae, and consequently affecting interactions between herbivores and the target plants, are glucosinolates (Bidart-Bouzat, Kliebenstein, 2008). Glucosinolates are present primarily in the Brassicas (Kim, Jander, 2007), but their influence on the resistance of plants to bacteria and fungi has also been proved (Griffiths et al., 2001). According to the origin (the amino acid they are derived from), glucosinolates are classified into three groups (classes) - aliphatic, indole and aromatic (Padilla et al., 2007). Cabbage flea beetles (Phyllotreta spp.) are among major harmful pests causing damage to the Brassicas (Trdan et al., 2005). Feeding on Brassica seedlings can cause plant death, while feeding at later developmental stages can reduce final yield due to uneven growth of plants (Trdan et al., 2005; Tansey et al., 2009). It has been established that during feeding cabbage flea beetles can transmit pathogens from infected to healthy plants (Toshova et al., 2009). Among the proven successful alternative methods of suppressing cabbage flea beetles are trap cropping (Trdan et al., 2005; Bohinc, Trdan, 2012), different times of sowing, different densities of plants per plot and crop rotation (Toshova et al., 2009).
Given that growing different plant species on a certain plot reduces the density of a harmful pest population (Bohinc, Trdan, 2012), and the secondary metabolites content (glucosinolates) varies among plant species (Moyes et al., 2000), we wished to study susceptibility of various Brassicas to cabbage flea beetles in view of using the trap cropping method in an environmentally friendly food production strategy.

The aim of our research was to determine glucosinolate content in different Brassica species during the growing season, to acquire the information about the suitability of different trap crops to flee beetle attack. In this way we would gain the results, which would be useful for growing cabbage without the use of synthetic insecticides.

\section{Materials and methods}

Plant material. A two-year (2009-2010) field experiment was carried out in the village Zgornja Lipnica $\left(46^{\circ} 19^{\prime} \mathrm{N}\right.$ latitude, $14^{\circ} 10^{\prime} \mathrm{E}$ longitude, $511 \mathrm{~m}$ a.s.l.) in Slovenia. During the growth period of cash crop (two hybrids of cabbage) in 2010, we were collecting samples of the selected above-ground parts of oil seed rape (Brassica napus L. ssp. oleifera $\mathrm{f}$. biennis), cv. 'Daniela' (supplier: Semenarna Ljubljana Ltd., Ljubljana, Slovenia), white mustard (Sinapis alba L.), cv. 'Zlata' (supplier: Semenarna Ljubljana Ltd., Ljubljana, Slovenia), oil radish (Raphanus sativus L. var. oleiformis), cv. 'Apoll' (supplier: Semenarna Ljubljana 
Ltd., Ljubljana, Slovenia), the early hybrid of white cabbage (Brassica oleracea L. var. capitata f. alba), cv. 'Tucana' (supplier: Semenarna Ljubljana Ltd., Ljubljana, Slovenia) and the medium-late cabbage hybrid (Brassica oleracea L. var. capitata f. alba), cv. 'Hinova' (producer: Bejo Zaden, the Netherlands; supplier: Agroprogress Ltd., Ljubljana, Slovenia).

Field evaluation. The field of $528 \mathrm{~m}^{2}$ was divided into four blocks. The three species of trap crops (oil seed rape, oil radish, white mustard) were sown within the blocks in separate treatments. The fourth treatment was the control, where no trap crop was sowed (bare surface). The arrangement of different Brassicas in our experiment is presented in Figure. In each treatment we also sowed both cabbage hybrids in separate sub-plots. Cabbage hybrids were the main crops in our experiment. The treatments within blocks were arranged randomly. The trap crops which were used for chemical analysis were sowed on 19 April 2010, while the cabbage seedlings were transplanted outdoors on 26 April 2010. The damage done on Brassicas by flea beetles was assessed by the 5 -grade visual scale. The plants were evaluated on a scale from 1 (no damage) to 5 (more than 25\% leaf area eaten), as follows: 2) up to $2 \%$ leaf area eaten, 3 ) between $3 \%$ and $10 \%$ leaf area eaten and 4) 11-25\% leaf area eaten (OEPP/EPPO, 2002). The seedlings of cabbage were grown in the Department of Agronomy's glasshouse at the Biotechnical Faculty, University of Ljubljana, Slovenia according to the protocol as described in Trdan et al. (2009).

\begin{tabular}{|c|c|c|c|c|}
\hline & & cabbage & & \\
\hline \multirow{4}{*}{$\begin{array}{l}\frac{u}{0} \\
\frac{0}{0} \\
\text { 音 }\end{array}$} & white mustard & \begin{tabular}{|l|} 
Tucana \\
Hinova \\
\end{tabular} & White mustard & \multirow{4}{*}{ 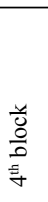 } \\
\hline & oil seed rape & $\begin{array}{l}\text { Tucana } \\
\text { Hinova }\end{array}$ & oil seed rape & \\
\hline & control & $\begin{array}{l}\text { Tucana } \\
\text { Hinova }\end{array}$ & control & \\
\hline & oil radish & $\begin{array}{l}\text { Tucana } \\
\text { Hinova }\end{array}$ & oil radish & \\
\hline \multirow{4}{*}{$\begin{array}{l}\frac{u}{0} \\
\text { o } \\
\text { 总 }\end{array}$} & oil seed rape & $\begin{array}{l}\text { Tucana } \\
\text { Hinova } \\
\end{array}$ & oil seed rape & \multirow{4}{*}{ 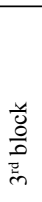 } \\
\hline & control & $\begin{array}{l}\text { Tucana } \\
\text { Hinova }\end{array}$ & control & \\
\hline & white mustard & \begin{tabular}{|l|} 
Tucana \\
Hinova
\end{tabular} & white mustard & \\
\hline & oil radish & \begin{tabular}{|l|} 
Tucana \\
Hinova
\end{tabular} & oil radish & \\
\hline \multirow{4}{*}{ 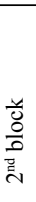 } & control & $\begin{array}{l}\text { Tucana } \\
\text { Hinova } \\
\end{array}$ & control & \multirow{4}{*}{ 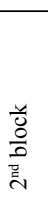 } \\
\hline & oil seed rape & $\begin{array}{l}\text { Tucana } \\
\text { Hinova }\end{array}$ & oil seed rape & \\
\hline & oil radish & $\begin{array}{l}\text { Tucana } \\
\text { Hinova }\end{array}$ & oil radish & \\
\hline & white mustard & $\begin{array}{l}\text { Tucana } \\
\text { Hinova }\end{array}$ & white mustard & \\
\hline \multirow{4}{*}{ 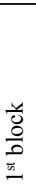 } & control & $\begin{array}{l}\text { Tucana } \\
\text { Hinova }\end{array}$ & control & \multirow{4}{*}{ 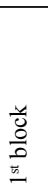 } \\
\hline & oil seed rape & $\begin{array}{l}\text { Tucana } \\
\text { Hinova }\end{array}$ & oil seed rape & \\
\hline & white mustard & $\begin{array}{l}\text { Tucana } \\
\text { Hinova } \\
\end{array}$ & white mustard & \\
\hline & oil radish & $\begin{array}{l}\text { Tucana } \\
\text { Hinova }\end{array}$ & oil radish & \\
\hline
\end{tabular}

Figure. Arrangement of different Brassicas in the field experiment

\section{Zgornja Lipnica, Slovenia}

Determination of glucosinolates. Plant material for the analysis of glucosinolates was sampled at different intervals. The plant material was cut down with scissors. Four samples of leaves or blossoms (flowers) of the species were collected on each assessment date. Individual samples (a part of the species) represented a representative sample of the plants in one plot. On certain assessment dates we collected, besides the samples of white mustard leaves ( 8 June, 3 July) and oil radish leaves ( 8 and 25 June, 31 July), also samples of blossoms of the trap crop species tested. Sampling of cabbage leaves was carried out at five different intervals, on 26 May, 16 June, 4 and 29 July, and 17 August 2010. Sampling of leaves of oil seed rape was carried out at five different intervals (19 May, 8 June, 3 and 31 July, and 31 August), while the sampling of oil radish and white mustard was performed at four intervals (the former: 19 May, 8 and 25 June, and 31 July; the latter 19 May, 8 and 25 June, and 3 July). Four samples of individual plant species were collected at individual intervals of assessment. An individual sample (leaves or blossoms or flowers) was the representative plant sample of one block. When analysing glucosinolates, the analysis of individual samples was repeated twice. The material was then freeze-dried (type: LIO-10P, producer: Kambič laboratorijska oprema, Slovenia) and homogenized before extraction of glucosinolates. The lyophilised samples were stored in $50 \mathrm{ml}$ bottles in a freezer (type: U3286S, producer: Sanyo) at $-80^{\circ} \mathrm{C}$. The glucosinolate extraction and analysis were performed according to ISO 9167:11992. As internal standards sinigrin or glucotropaeolin $\left(\mathrm{C}_{2}\right.$ Bioengineering ApS, Denmark) were added. The extracted glucosinolates were purified on a $1.5 \mathrm{~cm}$ DEAE Sephadex A-25 anion exchange column. The column was washed twice with $1 \mathrm{ml}$ distilled water loaded with $2 \mathrm{ml}$ of the glucosinolates extract and then washed twice with $1 \mathrm{ml} 20 \mathrm{mM} \mathrm{NaAc}$-solution and treated with sulphatase (75 $\mu \mathrm{L}$ and $25 \mathrm{mg} \mathrm{ml}^{-1}$ ). After an overnight reaction at room temperature the desulfoglucosinolates were eluted with distilled water $(2 \times 1 \mathrm{ml})$. The eluate was filtered over $0.45 \mu \mathrm{m}$ filter and then sample was ready for HPLC (high performance liquid chromatography) analysis.

For glucosinolate (GLS) quantification, twenty microlitres of desulfoglucosinolates solution were run on an Agilent 1200 Series HPLC system (Palo Alto, USA) at $2 \mathrm{ml} \mathrm{min}^{-1}$. The column was a Discovery C18, $25 \mathrm{~cm}$ $\times 4.6 \mathrm{~mm}, 5 \mu \mathrm{m}$ (Supelco). The mobile phases were water and methanol, running time: $28 \mathrm{~min}$. The gradient changed as follows: $100 \% \mathrm{~A}$ for $1 \mathrm{~min}$, then in $20 \mathrm{~min}$ to $20 \% \mathrm{~B}$, followed by $100 \% \mathrm{~B}$ for $5 \mathrm{~min}$. Afterwards the column was equilibrated at $100 \%$ A for $3 \mathrm{~min}$. The desulfoglucosinolates were detected with diode array detector at $229 \mathrm{~nm}$. The desulfoglucosinolates were identified with external standards $\left(\mathrm{C}_{2}\right.$ Bioengineering ApS, Denmark). The certified reference material used was BCR-367R. The content of each GLS was back calculated and expressed in micromoles per gram $\left(\mu \mathrm{mol} \mathrm{g}{ }^{-1}\right)$ of dry seed.

Data analysis. Prior to statistical analysis, the experimental results were statistically evaluated by the program Statgraphics Centurion XVI (2009). The differences between values of glucosinolates during the growth period and between individual plant species were calculated by analysing the variance $(A N O V A)$ and Duncan's test of multiple comparisons $(P<0.05)$. We calculated correlations between the concentration of an individual glucosinolate and level of injury caused by flea beetles on the plant species.

\section{Results and discussion}

Content of glucosinolates in different Brassicas. The results of the statistical analysis show that the glucoiberin content is significantly influenced by plant species $(P=0.0233, F=4.39, \mathrm{Df}=2)$, while the content between leaves and blossoms (flowers) does not vary $(P=0.3544, F=0.3544, \mathrm{Df}=3)$. The glucoiberin content in the samples of white mustard, oil seed rape, oil radish was below detection limit (in all cases $<0.1 \mu \mathrm{mol} \mathrm{g}^{-1}$ of dry seed (ds), while the samples of the cabbage hybrid 'Hinova' had the average content $0.33 \pm$ $0.08 \mu \mathrm{mol} \mathrm{g}^{-1} \mathrm{ds}$, and the samples of the hybrid 'Tucana' 
$0.38 \pm 0.09 \mu \mathrm{mol} \mathrm{g}^{-1} \mathrm{ds}$ (Table 1). The Brassicaceae species used in our experiment displayed no significant differences in the gluconapin content $(P=0.0686$, $F=3.55$, Df $=1$ ), while the glucoraphenin content was significantly influenced by individual Brassicaceae species $(P=0.0003, F=9.89, \mathrm{Df}=2)$. The average glucoraphenin content was significantly higher in oil

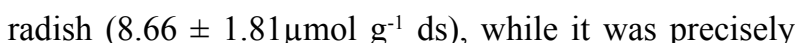
above the detection limit in the samples of both cabbage hybrids $\left(<0.1 \mu \mathrm{mol} \mathrm{g}{ }^{-1} \mathrm{ds}\right)$. The epiprogoitrin content was influenced by individual species $(P=0.0055, F=10.29$, $\mathrm{Df}=2)$, significant differences were detected also between leaves and blossoms (flowers) of the plants $(P<0.0001$, $F=32.15, \mathrm{Df}=1)$.

Table 1. Average values of glucosinolates occurring in different Brassica species (in $\mu \mathrm{mol} \mathrm{g}{ }^{-1} \mathrm{ds}$ )

\begin{tabular}{|c|c|c|c|c|c|c|}
\hline \multirow[b]{2}{*}{ Systematic name } & \multirow[b]{2}{*}{ Trivial name } & \multirow[b]{2}{*}{ Oil radish } & \multirow[b]{2}{*}{ Oil seed rape } & \multirow[b]{2}{*}{ White mustard } & \multicolumn{2}{|c|}{ Cabbage } \\
\hline & & & & & 'Hinova' & 'Tucana' \\
\hline \multicolumn{7}{|l|}{ Aliphatic } \\
\hline 3-Methlysufinylpropyl & Glucoiberin & $<0.1$ & $<0.1$ & $<0.1$ & $0.33 \pm 0.08$ & $0.38 \pm 0.09$ \\
\hline 2 (R)-2-Hydroxy-3-butenyl & Prog & $<0.1$ & $1.55 \pm 0.51$ & $<0.1$ & $1.13 \pm 0.02$ & $0.27 \pm 0.03$ \\
\hline 2 (S)-2-Hydroxy-3-butenyl & Epiprogoitrin & - & $0.19 \pm 0.06$ & $2.45 \pm 0.38$ & $<0.1$ & $<0.1$ \\
\hline 2-Propenyl & Sinigrin & - & - & - & $0.30 \pm 0.03$ & $0.35 \pm 0.06$ \\
\hline $3-\mathrm{B}$ & Gluc & - & $0.38 \pm 0$ & - & $0.17 \pm 0.03$ & $0.24 \pm 0.10$ \\
\hline 4-Methylsulfinyl-3-butenyl & Gluco & $66 \pm 1.81$ & $0.99 \pm($ & $0.51 \pm 0.19$ & $<0.1$ & $<0.1$ \\
\hline \multicolumn{7}{|l|}{ Indole } \\
\hline 3-Indolmethyl & Glucobrassicin & $3.24 \pm 0.86$ & $1.39 \pm 0.49$ & $1.71 \pm 0.88$ & $0.40 \pm 0.15$ & $0.79 \pm 0.27$ \\
\hline \multicolumn{7}{|l|}{ Aromatic } \\
\hline $\begin{array}{r}\text { 2-Phe } \\
4-\mathrm{Hvdn}\end{array}$ & $\begin{array}{c}\text { Gluconasturtiin } \\
\text { Sinalbin }\end{array}$ & $\begin{array}{c}<0.1 \\
0.36+0.12\end{array}$ & $\begin{array}{c}0.13 \pm 0.04 \\
11.16 \pm 650\end{array}$ & $3012+552$ & $\begin{array}{l}<0.1 \\
<0.1\end{array}$ & $\begin{array}{l}<0.1 \\
<0.1\end{array}$ \\
\hline
\end{tabular}

Note. $<0.1$ - glucosinolate present below detection level.

The content of the aliphatic glucosinolate was in comparison to leaves $\left(0.21 \pm 0.03 \mu \mathrm{mol} \mathrm{g}^{-1} \mathrm{ds}\right)$ significantly higher in the blossom samples $\left(2.81 \pm 0.01 \mu \mathrm{mol} \mathrm{g} \mathrm{g}^{-1} \mathrm{ds}\right)$ (Table 2). Plant species did not significantly affect the

progoitrin content $(P=0.5088, F=0.80, \mathrm{Df}=3)$, the content also did not differ between leaves and blossoms (flowers) $(P=0.5551, F=0.72, \mathrm{Df}=3)$.

Table 2. Average values of glucosinolates occurring in different Brassica species ( $\left.\mu \mathrm{mol} \mathrm{g}^{-1} \mathrm{ds}\right)$ through growth period, related to different plant parts

\begin{tabular}{|c|c|c|c|c|c|c|c|c|c|c|c|}
\hline Date & Plant species & Plant part & GIB & PRO & SIN & E-PRO & GRE & GNA & SLB & GBS & GST \\
\hline 1905 & oil radish & leaves & $<0.1$ & $<0.1$ & - & - & $0.22 \pm 0.15$ & $<0.1$ & $0.12 \pm 0.09$ & $8.84 \pm 0.07$ & $<0.1$ \\
\hline 0806 & oil radish & leaves & $<0.1$ & $<0.1$ & - & - & $0.41 \pm 0.10$ & $<0.1$ & $<0.1$ & $0.15 \pm 0.01$ & $<0.1$ \\
\hline 0806 & oil radish & flowers & $<0.1$ & $<0.1$ & - & - & $13.52 \pm 0.10$ & $<0.1$ & $0.53 \pm 0.04$ & $0.22 \pm 0.06$ & $<0.1$ \\
\hline 2506 & oil radish & leaves & $<0.1$ & $<0.1$ & - & - & $0.29 \pm 0.10$ & $<0.1$ & $0.52 \pm 0.03$ & $0.24 \pm 0.04$ & $<0.1$ \\
\hline 2506 & oil radish & flowers & $<0.1$ & $<0.1$ & - & - & $16.42 \pm 0.03$ & $<0.1$ & $0.22 \pm 0.11$ & $10.87 \pm 0.17$ & $<0.1$ \\
\hline 107 & oil radish & leaves & $<0.1$ & $<0.1$ & - & - & $2.06 \pm 0.05$ & $<0.1$ & $<0.1$ & $1.14 \pm 0.05$ & $<0.1$ \\
\hline 3107 & oil radish & flowers & $<0.1$ & $<0.1$ & - & - & $16.31 \pm 0.84$ & $<0.1$ & $<0.1$ & $0.53 \pm 0.11$ & $<0.1$ \\
\hline $1905 \mathrm{v}$ & white mustard & leaves & $<0.1$ & $<0.1$ & - & $0.24 \pm 0.11$ & $0.79 \pm 0.13$ & - & $34.77 \pm 0.09$ & $6.59 \pm 0.04$ & - \\
\hline $0806 \mathrm{v}$ & white mustard & leaves & $<0.1$ & $<0.1$ & - & $<0.1$ & $0.18 \pm 0.01$ & - & $3.51 \pm 0.11$ & $<0.1$ & - \\
\hline 0806 v & white mustard & flowers & $<0.1$ & $<0.1$ & - & $2.14 \pm 0.10$ & $<0.1$ & - & $25.85 \pm 0.32$ & $0.08 \pm 0.02$ & - \\
\hline $2506 \mathrm{v}$ & white mustard & flowers & $<0.1$ & $<0.1$ & - & $1.99 \pm 0.04$ & $0.09 \pm 0.01$ & - & $74.77 \pm 0.19$ & $0.18 \pm 0.02$ & - \\
\hline $0307 \mathrm{~V}$ & white mustard & leaves & $<0.1$ & $<0.1$ & - & $<0.1$ & $0.82 \pm 0.04$ & - & $6.75 \pm 1.45$ & $0.31 \pm 0.09$ & - \\
\hline $0307 \mathrm{~V}$ & white mustard & flowers & $<0.1$ & $<0.1$ & - & $2.30 \pm 0.05$ & $<0.1$ & - & $56.93 \pm 0.07$ & $0.15 \pm 0.06$ & - \\
\hline 1905 & oil seed rape & leaves & $<0.1$ & $1.03 \pm 0.04$ & - & $0.375 \pm 0.04$ & $0.13 \pm 0.05$ & $0.22 \pm 0.04$ & $18.41 \pm 0.15$ & $2.16 \pm 0.04$ & $0.21 \pm 0$ \\
\hline 0806 & oil s & leaves & $<0.1$ & $15 \pm 0$. & - & $<0.1$ & $3.82 \pm 0.15$ & $0.20 \pm 0$ & $<0.1$ & $0.12 \pm 0.05$ & $<0.1$ \\
\hline 307 & oil seed 1 & leaves & $<0.1$ & $0.23 \pm 0.05$ & - & $<0.1$ & $0.09 \pm 0.06$ & $0.29 \pm 0$ & $<0.1$ & $0.33 \pm 0.04$ & $<0.1$ \\
\hline 3107 & oil seed rape & leaves & $<0.1$ & $0.27 \pm 0.04$ & - & $<0.1$ & $0.12 \pm 0.04$ & $0.40 \pm 0.17$ & $<0.1$ & $0.49 \pm 0.12$ & $<0.1$ \\
\hline 3108 & $\begin{array}{l}\text { oil seed rape } \\
\text { Cabbage: }\end{array}$ & leaves & $<0.1$ & $3.64 \pm 0.56$ & - & $0.13 \pm 0.01$ & $0.13 \pm 0.05$ & $0.60 \pm 0.12$ & $<0.1$ & $4.30 \pm 0.17$ & $0.08 \pm 0 .($ \\
\hline 2605 & 'Hinova' & leaves & $0.16 \pm 0.02$ & $<0.1$ & $0.25 \pm 0.21$ & $<0.1$ & $<0.1$ & $<0.1$ & $<0.1$ & $1.46 \pm 0.02$ & $<0.1$ \\
\hline 1606 & 'Hinova' & leaves & $<0.1$ & $<0.1$ & $0.25 \pm 0.22$ & $<0.1$ & $<0.1$ & $<0.1$ & $<0.1$ & $0.02 \pm 0.02$ & $<0.1$ \\
\hline 0407 & 'Hinova' & leaves & $0.11 \pm 0.02$ & $<0.1$ & $<0.1$ & $<0.1$ & $<0.1$ & $0.23 \pm 0.03$ & $<0.1$ & $0.04 \pm 0.01$ & $<0.1$ \\
\hline 2907 & 'Hinova' & leaves & $0.82 \pm 0.16$ & $1.13 \pm 0.07$ & $<0.1$ & $<0.1$ & $<0.1$ & $0.13 \pm 0.02$ & $<0.1$ & $0.04 \pm 0.04$ & $<0.1$ \\
\hline 1708 & 'Hinova' & leaves & $0.22 \pm 0.13$ & $<0.1$ & $0.35 \pm 0.06$ & $<0.1$ & $<0.1$ & $<0.1$ & $<0.1$ & $0.04 \pm 0.01$ & $<0.1$ \\
\hline 2605 & 'Tucana' & leaves & $0.35 \pm 0.04$ & $<0.1$ & $0.41 \pm 0.09$ & $<0.1$ & $<0.1$ & $0.14 \pm 0$ & $<0.1$ & $2.34 \pm 0.05$ & $<0.1$ \\
\hline 1606 & 'Tucana' & leaves & $<0.1$ & $<0.1$ & $<0.1$ & $<0.1$ & $<0.1$ & $0.14 \pm 0.02$ & $<0.1$ & $0.05 \pm 0.05$ & $<0.1$ \\
\hline 0407 & 'Tucana' & leaves & $<0.1$ & $<0.1$ & $<0.1$ & $<0.1$ & $<0.1$ & $0.06 \pm 0.02$ & $<0.1$ & $0.04 \pm 0.04$ & $<0.1$ \\
\hline 2907 & 'Tucana' & leaves & $0.56 \pm 0.1$ & $0.27 \pm 0.12$ & $<0.1$ & $<0.1$ & $<0.1$ & $0.49 \pm 0.15$ & $<0.1$ & $1.22 \pm 0.05$ & $<0.1$ \\
\hline 1708 & 'Tucana' & leaves & $0.33 \pm 0.12$ & $<0.1$ & $0.31 \pm 0.04$ & $<0.1$ & $<0.1$ & $0.14 \pm 0.02$ & $<0.1$ & $0.15 \pm 0.12$ & $<0.1$ \\
\hline
\end{tabular}

Note. GIB - glucoiberin, PRO - progoitrin, SIN - sinigrin, E-PRO - epiprogoitrin, GRE - glucoraphenin, GNA - gluconapin, SLB - sinalbin, GBS - glucobrassicin, GST - gluconasturtiin; $<0.1$ - glucosinolate present below detection level.

Among indole glucosinolates glucobrassicin was detected in all plant species, its content, however, varied significantly among the plant species $(P=0.0282, F=3.15$, $\mathrm{Df}=3$ ), from $0.40 \pm 0.15 \mu \mathrm{mol} \mathrm{g}^{-1} \mathrm{ds}$ in the samples of the cabbage hybrid 'Hinova' to $3.24 \pm 0.86 \mu \mathrm{mol} \mathrm{g}^{-1} \mathrm{ds}$ in the samples of oil radish (Table 1). No significant differences in glucobrassicin content of individual above-ground plant organs were detected $(P=0.1273, F=1.94$, Df $=3)$. In detecting aromatic glucosinolates we established that the gluconasturtiin content was influenced by the Brassicaceae species $(P=0.04643, F=0.12$, Df $=1)$.
There were no differences detected in the gluconasturtiin content of various plant organs $(P=0.7643, F=0.49$, $\mathrm{Df}=1)$. Gluconasturtiin was in oil radish samples present in traces $\left(<0.1 \mu \mathrm{mol} \mathrm{g}^{-1} \mathrm{ds}\right)$, meanwhile its presence in cabbage samples was below detection level. The sinalbin content varied with different plant species $(P=0.0090$, $F=5.50$, Df $=1)$, as well as with individual plant organs $(P=0.0001, F=20.84, \mathrm{Df}=1)$. The sinalbin content was significantly higher in the samples of white mustard $\left(30.12 \pm 5.52 \mu \mathrm{mol} \mathrm{g}^{-1} \mathrm{ds}\right)$; in the samples of oil seed rape it was $11.16 \pm 6.50 \mu \mathrm{mol} \mathrm{g}{ }^{-1} \mathrm{ds}$, while in the samples 
of cabbage, early and mid-late hybrid, no sinalbin was detected.

Correlation between level of injury caused by cabbage flea beetles on plants belonging to trap crop and concentration of glucosinolate. We discovered a very high negative correlation $(r=-0.99)$ between the gluconasturtiin content and level of injury done by flea beetles (Table 3$)$. A low negative correlation $(r=-0.22)$ was established between the glucoraphenin content in the oil seed rape samples and level of injury. A stimulating influence of epiprogoitrin on feeding of cabbage flea beetles was detected in the white mustard samples $(r=0.56)$, while the epiprogoitrin content negatively influenced feeding habits on oil seed rape $(r=-0.80)$. The correlation between level of injury and the glucoiberin content in the samples of oil seed rape is explained with the model $\hat{Y}=4.15-0.416667^{*}$. The results of the statistical analysis show stimulating influence of glucobrassicin on feeding of the species from the genus Phyllotreta on oil seed rape $(r=0.39)$, while higher glucobrassicin content in the oil radish $(r=-0.32)$ and white mustard $(r=-0.64)$ negatively influenced the intensity of the flea beetles feeding (Table 3 ). A moderate positive correlation $(r=0.67)$ was established between level of injury done by flea beetles and gluconapin content in the oil seed rape samples. In the oil seed rape samples we also detected stimulating influence of sinalbin $(r=0.61)$ and progoitrin $(r=0.51)$ on feeding intensity of flea beetles.

Table 3. Correlation between level of injury caused by Phyllotreta spp. and glucosinolate (GLS) concentration $(P<0.05$ Duncan's multiple range test $)$ in three trap crop species

\begin{tabular}{|c|c|c|c|c|c|c|c|c|c|c|c|c|}
\hline \multirow{2}{*}{ GLS } & \multicolumn{4}{|c|}{ Oil seed rape } & \multicolumn{4}{|c|}{ Oil radish } & \multicolumn{4}{|c|}{ White mustard } \\
\hline & $r$ & $p$ & $\mathrm{a}$ & $\mathrm{b}$ & $r$ & $p$ & $\mathrm{a}$ & $\mathrm{b}$ & $r$ & $p$ & $\mathrm{a}$ & $\mathrm{b}$ \\
\hline GST & -0.99 & 0.0646 & 4.5913 & -6.7922 & & & $\mathrm{x}$ & & & & - & \\
\hline GRE & -0.22 & 0.3863 & 3.4482 & -0.0293 & 0.11 & 0.6239 & 3.3539 & 0.0099 & -0.09 & 0.8127 & 2.7598 & -0.0739 \\
\hline E-PRO & -0.80 & 0.1950 & 4.1831 & -2.7732 & & & - & & 0.56 & $0.0364 *$ & 2.5833 & 0.13010 \\
\hline GIB & -1.00 & - & 4.1500 & -0.4166 & & & $\mathrm{x}$ & & & & $\mathrm{x}$ & \\
\hline GBS & 0.39 & 0.1062 & 3.3010 & 0.0812 & -0.32 & 0.0998 & 3.5159 & -0.0478 & -0.64 & $0.0019 *$ & 2.9538 & -0.0635 \\
\hline GNA & 0.67 & $0.0045^{*}$ & 2.8510 & 1.5742 & & & $\mathrm{x}$ & & & & - & \\
\hline SLB & 0.61 & 0.2724 & 3.0531 & 0.0109 & 0.13 & 0.7780 & 2.8938 & 0.1441 & 0.04 & 0.8526 & 2.9101 & 0.0005 \\
\hline PRO & 0.51 & 0.1035 & 3.3192 & 0.1461 & & & $\mathrm{x}$ & & & & $\mathrm{x}$ & \\
\hline SIN & & & & & & & . & & & & & \\
\hline
\end{tabular}

Notes. GST - gluconasturtiin, GRE - glucoraphenin, E-PRO - epiprogoitrin, GIB - glucoiberin, GBS - glucobrassicin, GNA - gluconapin, SLB - sinalbin, PRO - progoitrin, SIN - sinigrin. $\mathrm{x}$ - because glucosinolate was present at trace level $\left(<0.1 \mu \mathrm{mol} \mathrm{g}{ }^{-1} \mathrm{ds}\right)$ we were not able to calculate correlation; $r$ - correlation coefficient, ${ }^{*}-p<0.05$, a - intercept, $\mathrm{b}-$ slope.

Correlation between level of injury caused by flea beetles on cash crops and glucosinolate concentration. A moderate positive correlation was established between the glucoiberin content in the midlate hybrid samples 'Hinova' and level of injury done by flea beetles $(r=0.52)$; while the correlation between the glucosinolate content and the level of injury on the early hybrid 'Tucana' plants is explained by the model $\hat{\mathrm{Y}}=2.39784-0.0448347^{*}$ glucoiberin (Table 4). The analysis of results shows stimulating influence of progoitrin on the intensity of feeding by flea beetles on the early hybrid plants $(r=1)$, while the correlation between the level of injury on the mid-late hybrid and the glucosinolate content is explained by the model $\hat{\mathrm{Y}}=2.25781+0.079386^{*}$ progoitrin. The analysis of results shows low (positive) correlation between the level of injury done by flea beetles and the sinigrin content in the mid-late hybrid samples $(r=0.31)$. Generally speaking, oil radish proved to be the most efficient trap crop, which was also confirmed in our previous study (Bohinc, Trdan, 2012). Significant preference towards feeding on white mustard was not shown in our study, nor in a similar experiment (Hiiesaar et al., 2006). We confirmed the findings of some researchers who found out that the glucosinolate content varied between different Brassicaceae species (Moyes et al., 2000), between plant organs (Bellostas et al., 2007), and the concentrations of these secondary metabolites varied also during the growth period (De Villena et al., 2007). Differences in the glucosinolate content were detected also in a single species - between two cabbage hybrids (Bellostas et al., 2007). In the studied Brassicaceae we detected aliphatic glucosinolates which are characteristic also of other Brassicaceae species (Cartea et al., 2008); their presence is genetically predetermined (Agerbirk et al., 2009).

Among indole glucosinolates we established the presence of glucobrassicin whose content was to some extent probably influenced also by temperatures (Kim, Jander, 2007). While the research results show negative influence of glucosinolates on generalists (Pontoppidian et al., 2005), stimulating influence is most frequently established with the specialists who feed exclusively on Brassicaceae (Nielsen et al., 2001). There is, however, not much known about the significance of individual glucosinolates in plant protection (Kim, Jander, 2007). In view of the fact that some plants (Bidart-Bouzat, Kliebenstein, 2008), including oil seed rape, are very susceptible to level of injury by various

Table 4. Correlation between level of injury caused by Phyllotreta spp. and glucosinolate (GLS) concentration $(P<0.05$ Duncan's multiple range test $)$ in two different cabbage hybrids as main crops

\begin{tabular}{|c|c|c|c|c|c|c|c|c|}
\hline \multirow{2}{*}{ GLS } & \multicolumn{4}{|c|}{ 'Tucana' } & \multicolumn{4}{|c|}{ 'Hinova' } \\
\hline & $r$ & $p$ & $\mathrm{a}$ & $\mathrm{b}$ & $r$ & $p$ & $\mathrm{a}$ & $\mathrm{b}$ \\
\hline GST & & & - & & & & - & \\
\hline GRE & & & $\mathrm{x}$ & & & & $\mathrm{x}$ & \\
\hline E-PRO & & & - & & & & - & \\
\hline GIB & -0.06 & 0.8649 & 2.3978 & 0.0448 & 0.52 & 0.0650 & 2.2123 & 0.3646 \\
\hline GBS & -0.08 & 0.7289 & 2.4449 & -0.0134 & -0.26 & 0.3010 & 2.3214 & -0.0853 \\
\hline GNA & -0.08 & 0.8001 & 2.4226 & 0.0416 & -0.03 & 0.9602 & 2.3601 & -0.0773 \\
\hline SLB & & & - & & & & - & \\
\hline PRO & 1.00 & - & 2.3323 & 1.1166 & 0.55 & 0.4535 & 2.2578 & 0.0793 \\
\hline SIN & -0.07 & 0.8737 & 2.3999 & -0.0797 & 0.31 & 0.4584 & 2.0568 & 0.7657 \\
\hline
\end{tabular}

Explanations under Table 3 
phytophagous insects (Valantin-Morison et al., 2007). These characteristic can be explained by the content of various chemical substances, also glucosinolates (BidartBouzat, Kliebenstein, 2008). The effect of glucosinolates on feeding of various herbivorous species can vary (Agerbirk et al., 2008). Besides stimulating effect of progoitrin on feeding of cabbage flea beetles with oil seed rape and the main crops, its presence can also have negative effects if plants with excessive glucosinolate content are used as fodder (Padilla et al., 2007; Sun et al., 2011). Consequently, the emphasis is on plant breeding, though no negative effects on human nutrition have been detected (Sun et al., 2011). The potential negative influence of glucobrassicin on feeding of cabbage flea beetles, which we proved by our research, can positively influence human nutrition, since the decomposition products of indole glucosinolates have positive (anticarcinogenic) effects on human health (Sun et al., 2011). Beneficial to human health are also some other glucosinolates including sinigrin, glucoiberin, progoitrin and gluconasturtiin (Sun et al., 2011).

In the past (Bodnaryk, 1991), one of the major "chemical" factors of defending white mustard against attacks by cabbage flea beetles was considered the presence of sinalbin. Abundance of sinalbin was also evaluated as an important defensive factor against Mamestra configurata (Ulmer et al., 2001). However, its presence can also have a stimulating effect on Pieris rapae feeding (Agerbirk et al., 2009). Oil seed rape can be used for fodder (Valantin-Morison et al., 2007), white mustard as a means to prevent nitrate leaching from agricultural soil during winter (Dorsainvil et al., 2005), and as a living mulch (Romaneckas et al., 2012), oil radish as a plant species affects the balance of carbon in soil (Mutegi et al., 2011). Results of our research indicate a potentially wider application of the studied Brassicaceae - also to protect other cruciferous plants against harmful pests. Their applicability for protecting plants against the pests which are numerous and thus harmful in Europe is manifested by the fact that registered synthetic pesticides are on the decrease (The list..., 2012) as they negatively influence our environment (Bommarco et al., 2011).

\section{Conclusions}

1. The tested alternative method of cabbage protection against the flea beetle adults proved to be efficient. The level of injury caused by flea beetles was significantly the highest on oil radish, thus oil radish proved to be the most suitable as trap crop.

2. Glucosinolate content differed between plant species and even between plant organs of the same Brassica species. Sinigrin was only present in cabbage cultivars; gluconapin was present in oil seed rape and cabbage cultivars. Glucoraphenin and sinalbin contents were only confirmed in Brassica trap crops. In comparison to different plant parts, glucoraphenin was more abundant in oil radish flowers than in leaves. Epiprogoitrin was only abundant in oil seed rape and white mustard, but below detection level in cabbage cultivars. Progoitrin, as the most abundant in oil seed rape and cabbage cultivars, was also present in oil radish and white mustard, but below detection level $\left(<0.1 \mu \mathrm{mol} \mathrm{g}^{-1}\right.$ dry seed). The level of glucoiberin was significantly the highest in cabbage cultivars, while gluconasturtiin was the most abundant in oil seed rape.

3. Glucobrassicin was the most abundant glucosinolate detected in our study. It was the most abundant in oil radish.

4. Based on the results of our study, we conclude that the glucosinolates content in different Brassicas can play a significant role in selection of mentioned field crops in the areas, where the cabbage is exposed to numerous pests. Additional tests are undoubtedly needed to confirm the applicability of these results in environmentally acceptable cabbage production.

\section{Acknowledgements}

The results presented in this paper were obtained by research work within the national project V4-1067, which is cofinanced by the Slovenian Research Agency, The Ministry of Agriculture and the Environment of the Republic of Slovenia. Jaka Rupnik is acknowledged for technical assistance.

Received 19102012 Accepted 12042013

\section{References}

Agerbirk N., De Vos M., Kim J. H., Jander G. 2009. Indole glucosinolate breakdown and its biological effects. Phytochem Review, 8 (1): 101-120 http://dx.doi.org/10.1007/s11101-008-9098-0

Bellostas N., Kachlicki P., Sørensen J. C., Sørensen H. 2007. Glucosinolate profiling of seeds and sprouts of $B$. oleracea varieties used for food. Scientia Horticulturae, 114 (4): 234-242 http://dx.doi.org/10.1016/j.scienta.2007.06.015

Bidart-Bouzat M. G., Kliebenstein D. J. 2008. Differential levels of insect herbivory in the field associated with genotypic variation in glucosinolates in Arabidopsis thaliana. Iournal of Chemical Fcologv. 34 (8): 1026-1037 http://dx.doi.org/10.1007/s10886-008-9498-z

Bodnaryk R. P. 1991. Developmental protile of sinalbin (p-hydroxybenzyl glucosinolate) in mustard seedlings, Sinapis alba L. and its relationship to insect resistance. Journal of Chemical Ecologv. 17 (8): 1543-1556 http://dx.doi.org/10.1007/BF00984687

Bohinc I., Irdan S. 2012. Trap crops for reducing damage caused by cabbage stink bugs (Eurydema spp.) and flea beetles (Phyllotreta spp.) on white cabbage: fact or fantasy. Journal of Food Agriculture and Environment, 10 (2): $1365-1370$

Bommarco R., Miranda F., Bylund H., Björkman C. 2011. Insecticides suppress natural enemies and increase pest damage in cabbage. Journal of Economic Entomology, 104 (3): 782-791 http://dx.doi.org/10.1603/EC10444

Breuker C. J., De Jong P. W., Victorir K., Vrieling K., Brakefield P. M. 2007. Pleiotropic effects associated with an allele enabling the flea beetle Phyllotreta nemorum to use Barbarea vulgaris as host plant. Evolutionary Ecology, 21 (1): 13-26 http://dx.doi.org/10.1007/s10682-006-9121-0

Carmona D., Lajeunese M. J., Johnson M. I. J. 2011. Plant traits that predict resistance to herbivores. Functional Ecology, 25 (2): $358-367$ http://dx.doi.org/10.1111/j.1365-2435.2010.01794.x

Cartea M. E., Rodriguez V.M., de Haro A., Velasco P., Ordás A. 2008. Variation of glucosinolates and nutrional value in nabicol (Brassica napus pabularia group). Euphytica, 159 (1-2): 111-122

De Villena F. A., Fritz V. A., Cohen J. D., Hutchison V. D. 2007. Changes in gluconasturtiin concentrations in chinese cabbage with increasing cabbage looper density. HortScience, 42 (6): 1337-1340

Dorsainvil F., Dürr C., Justes E., Carrera A. 2005. Characterisation and modelling of white mustard (Sinapis alba L.) emergence under several sowing conditions. Furonean Iournal of Agronomy, 23 (2): 146-158 http://dx.doi.org/10.1016/j.eja.2004.11.002

Griftiths D. W., Deighton N., Birch A. N. E., Patrian B., Baur R. Städler E. 2001. Identification of glucosinolates on the leaf surface of plants from the Cruciferae and other closely related snecies. Phvtochemistrv. 57 (2): 693-700 http://dx.doi.org/10.1016/S0031-9422(01)00138-8

Hiiesaar K., Metspalu L., Jõgar K. 2006. Attractiveness and susceptibility of Brassica rapa, B. napus and Sinapis alba to the flea beetles (Coleoptera: Chrysomelidae). Agronomy Research, 4: 191-196 
Jõgar K., Metspalu L., Hiiesaar K., Ploomi A., Kuusik A., Men'shykova A. L. 2008. Abundance of the small white (Pieris rapae L.) on different cabbage cultivars. Zemdirbyste-Agriculture, 95 (3): 88-93

Kim J. K., Jander G. 2007. Myzus persicae (green peach aphid) feeding on Arabidopsis induces the formation of a deterrent indole glucosinolate. Plant Journal, 49 (6): 1008-1019 http://dx.doi.org/10.1111/j.1365-313X.2006.03019.x

Moyes C. L., Collin H. A., Britton G., Raybould A. F. 2000. Glucosinolates and differential herbivory in wild populations of Brassica oleracea. Journal of Chemical Ecology, 26 (11): 2625-2641 http://dx.doi.org/10.1023/A:1005549115751

Mutegi J. K., Petersen B. J., Munkholm L. J., Hansen E. M. 2011. Belowground carbon input and translocation potential of fodder radish cover-crop. Plant Soil, 344 (1-2): 159-175 http://dx.doi.org/10.1007/s11104-011-0737-7

Nielsen J. K., Hansen M. L., Agerbirk N., Petersen B. L., Halkier B. A. 2001. Responses of the flea beetles Phyllotreta nemorum and $P$. cruciferae to metabolically engineered Arabidopsis thaliana with an altered glucosinolate profile. Chemoecologv. 11 (2): 75-83 http://dx.doi.org/10.1007/PL00001835

OEPP/EPPO. 2002. Guidelines for the efficancy evaluation of insecticides. Phyllotreta spp. on rape. OEPP/EPPO Bulletin, 32: 361-365

Padilla G., Cartea M. E., Velasco P., de Haro A., Ordás A. 2007. Variation of glucosinolates in vegetable crops of Brassica rapa. Phytochemistry. 68 (4): 536-545 http://dx.doi.org/10.1016/j.phytochem.2006.11.017

Pontoppidan B., Hopkins R., Rask L., Meijer J. 2005. Differential wound induction of the myrosinase system in oilseed rape (Brassica napus): contrasting insect damage with mechanical damage. Plant Science. 168 (3): 715-722 http://dx.doi.org/10.1016/j.plantsci.2004.10.003

Romaneckas K., Adamavičienè A., Pilipavičius V., Šarauskis E., Avižienytė D., Buragienè S. 2012. Interaction of maize and living mulch. Crop weediness and productivity. Zemdirbyste-Agriculture, 99 (1): 23-30

Statgraphics Centurion XVI. 2009. Statpoint Technologies Inc., Warrenton, USA

ISSN 1392-3196 / e-ISSN 2335-8947

Zemdirbyste-Agriculture, vol. 100, No. 2 (2013), p. 199-204

DOI $10.13080 /$ z-a.2013.100.026
Sun B., Liu N., Zhao Y., Yan, H., Wang Q. 2011. Variation of glucosinolates in three edible parts of Chinese kale (Brassica alboglabra Bailey) varieties. Food Chemistry, 124 (3): 941-947 http://dx.doi.org/10.1016/j.foodchem.2010.07.031

Tansey J. A., Dosdall L. M., Keddie B. A. 2009. Phyllotreta cruciferae and Phyllotreta striolata responses to insecticidal seed treatments with different models of action. Journal of Applied Entomology. 133 (3): 201-209 http://dx.doi.org/10.1111/j.1439-0418.2008.01321.x

The list of registrated plant protection product on 16.02.2012. The Ministry of Agriculture and the Environment of the Republic of Slovenia. Phytosanitary Administration of the Republic of Slovenia. $<\mathrm{http} / /$ spletni2.furs.gov.si/FFS/ REGSR/index.htm> [accessed 1602 2012] (in Slovenian)

Toshova T. B., Csonka E., Subschev M. A., Tóth M. 2009. The seasonal activity of flea beetles in Bulgaria. Journal of Pest Science. 82 (3): 295-303 http://dx.doi.org/10.1007/s10340-009-0254-0

Trdan S., Valič N., Žnidarčič D., Vidrih M., Bergant K., Zlatič E., Milevoj L. 2005. The role of Chinese cabbage as a trap crop for flea beetles (Coleoptera: Chrysomelidae) in production of white cabbage. Scientia Horticulturae. 106 (1): 12-24 http://dx.doi.org/10.1016/j.scienta.2005.03.005

Trdan S., Valič N., Vovk I., Martelanc M., Simonovska B., Vidrih R., Vidrih M., Žnidarčič D. 2009. Natural resistance of cabbage against three insect pests. Integrated Protection of Field Vegetables. Collier R. (ed.). IOBC/wprs Bulletin, 51: 93-106

Ulmer B., Gillot C., Erlandson M. 2001. Feeding preferences, growth, and development of Mamestra configurata (Lepidoptera: Noctuidae) on Brassicaceae. Canadian Entomologist. 133 (4): 509-519 http://dx.doi.org/10.4039/Ent133509-4

Valantin-Morison M., Meynard J. M., Doré T. 2007. Effects of crop management and surrounding field environment on insect incidence in organic winter oilseed rape (Brassica napus L.). Crop Protection, 26 (8): 1108-1120 http://dx.doi.org/10.1016/j.cropro.2006.10.005

\title{
Gliukozinolatai kaip natūrali bastutinių augalų apsauga nuo kryžmažiedinès spragès (Phyllotreta spp.) pažeidimų
}

\author{
T. Bohinc ${ }^{1}$, I. J. Košir ${ }^{2}$, S. Trdan ${ }^{1}$ \\ ${ }^{1}$ Liublijanos universitetas, Slovėnija \\ ${ }^{2}$ Slovenijos apynių ir alaus tyrimų institutas
}

\begin{abstract}
Santrauka
Kryžmažiedinès spragès, mintančios ịvairiais bastutiniais augalais, gali sumažinti jų produktyvumą. Siekiant mažinti sintetiniu pesticidu naudojimą ir skatinti aplinkos apsaugą, turètų būti panaudota natūrali augalu geba apsisaugoti nuo kenkèjų pažeidimų. 2009-2010 m. atlikto tyrimo rezultatai parodè, kad gliukozinolatų kiekis ivvairuoja priklausomai nuo augalo rūšies ir organo. Visų rūšių bastutiniuose augaluose (kopūstuose, aliejiniuose ridikuose, rapsuose ir baltosiose garstyčiose) tarp indolinių gliukozinolatų buvo nustatytas gliukobrasicinas, kurio itaka kryžmažiedinėms spragèms skyrèsi priklausomai nuo augalo rūšies. Tyrimo metu nustatytas stiprus neigiamas koreliacinis ryšys $(r=-0,99)$ tarp gliukonasturtino kiekio rapsų augaluose ir kryžmažiedinių spragių pažeidimo intensyvumo. Tarp gliukonapino, sinalbino, progoitrino kiekių rapsuose ir kryžmažiedinių spragiu pažeidimų intensyvumo nustatyti vidutinio stiprumo koreliaciniai ryšiai (atitinkamai $r=0,67, r=0,61$ ir $r=0,51$ ). Esminès gliukobrasicino ittakos kryžmažiediniu spragiu pažeidimams rapsuose nebuvo nustatyta, tačiau šis gliukozinolatas turẻjo neigiamos įtakos spragių pažeidimams aliejiniuose ridikuose $(r=-0,32)$ ir baltosiose garstyčiose $(r=-0,64)$. Nustatyta, kad aliejinis ridikas yra tinkamiausia rūšis privilioti kryžmažiedines sprages ir gali būti naudojamas kaip spąstai šiam kenkejui. Padaryta išvada, kad bastutinių augalų apsaugos nuo kryžmažiedinių spragių intensyvumas gali priklausyti nuo gliukozinolatų kiekio augaluose, tačiau siekiant šio tyrimo rezultatus pritaikyti ekologiškai auginamiems kopūstams, reikia papildomų tyrimų.
\end{abstract}

Reikšminiai žodžiai: aliejinis ridikas, baltoji garstyčia, gliukozinolatai, gūžinis kopūstas, Phyllotreta spp., rapsas. 